Article

\title{
Polyphenols, Antioxidant, Antibacterial, and Biofilm Inhibitory Activities of Peel and Pulp of Citrus medica L., Citrus bergamia, and Citrus medica cv. Salò Cultivated in Southern Italy
}

\author{
Florinda Fratianni ${ }^{1}\left(\mathbb{D}\right.$, Autilia Cozzolino ${ }^{2}(0)$, Vincenzo De Feo ${ }^{3, *}{ }^{\circ}$, Raffaele Coppola ${ }^{2}$, \\ Maria Neve Ombra ${ }^{1}$ and Filomena Nazzaro ${ }^{1, *}$ \\ 1 Istituto di Scienze dell'Alimentazione, Consiglio Nazionale delle Ricerche (ISA-CNR), via Roma 64, \\ 83100 Avellino, Italy; fratianni@isa.cnr.it (F.F.); marianeve.ombra@isa.cnr.it (M.N.O.) \\ 2 Department of Agricultural, Environmental and Food Sciences, DiAAA-University of Molise, Via de Sanctis \\ s.n.c., 83100 Campobasso, Italy; a.cozzolino@studenti.unimol.it (A.C.); coppola@unimol.it (R.C.) \\ 3 Department of Pharmacy, University of Salerno, Via Giovanni Paolo II, 132, 84084 Fisciano (Salerno), Italy \\ * Correspondence: defeo@unisa.it (V.D.F.); filomena.nazzaro@cnr.it (F.N.); Tel.: +39-08-996-9751(V.D.F.); \\ +39-08-2529-9102 (F.N.)
}

Academic Editors: Paola Di Donato and Brigida Silvestri

Received: 19 November 2019; Accepted: 11 December 2019; Published: 13 December 2019

check for updates

\begin{abstract}
The aim of this paper was to study the polyphenols of peel and pulp of three Citrus taxa-Citrus medica, Citrus bergamia, and Citrus medica cv. Salò-cultivated in the Cosenza province, Southern Italy, and to evaluate their antioxidant and antibacterial activity, performed against Escherichia coli, Listeria monocytogenes, Pseudomonas aeruginosa, Staphylococcus aureus, and Pectobacterium carotovorum. Furthermore, we assessed the inhibitory effect of the extracts on bacterial capacity to form biofilm, and on the metabolic activity of the cells present therein. The results indicated that such extracts could find new potential applications in the field of natural antioxidant and anti-bacterial agents in pharmaceutics, agriculture, and food fields.
\end{abstract}

Keywords: Citrus medica; Citrus bergamia; Citrus medica cv. Salò; polyphenols; biofilm; antibacterial activity

\section{Introduction}

In recent decades, the international market has been characterized by increased consumer demand for products with improved quality and safety features. Fruit and vegetables contain very precious metabolites with antioxidant activity, which also represent a defense strategy of the plant organism in fighting biotic attacks from pathogenic microorganisms and from chemical-physical stresses due to environmental conditions. Several studies have shown that continuous treatment with conventional antibiotics lead to the development of bacterial resistance [1]. Biofilm formation and bacterial antibiotic resistance constitute problems of particular relevance for human health. In fact, the emergence of antibiotic resistance among pathogenic microorganisms, also through the formation of biofilm, is encouraging research to identify new antimicrobials from various sources, such as medicinal plants that could be capable to act as alternative treatments to commercial antimicrobial drugs, mainly in the case of particularly resistant and aggressive bacteria [2]. The Mediterranean area is rich in vegetal biodiversity and, since ancient times, fruits, herbs, spices, and vegetables have been used in traditional medicine to treat several diseases, including infections caused by bacteria and fungi. Some of the most diffused products, present on both sides of the Mediterranean Sea, are represented by species of genus Citrus, belonging to the Rutaceae family [3]. In particular, Citrus medica L., the cedar, was introduced 
to Italy by Hebrews, who promoted its cultivation on the Calabrian and Amalfi coasts and Garda Lake $[4,5]$. The different cultivars of C. medica L. are generally divided into two groups: "acidic" and "sweet" cedars. The first one, like the typical species, have red-purple flowers and buds and acidic pulp; the latter have white flowers and a sweeter pulp. Among the acidic cedars there are C. medica cv. Diamante, and the so-called "Hand of Buddha" (with ornamental fruits without pulp). The Corsican and the $C$. medica cv. Salò are among the sweet cedars. Finally, other cultivars can be considered as hybrids between lemons and cedars; they produce fruits resembling cedar due to the size and thickness of the peel, quite suitable for candy manufacture, while the appearance is similar to a lemon.

The Calabria region is famous for the production of different Citrus species, such as cedar, cedar of Salò, and bergamot. Cedar (Citrus medica L.) is also known because it is considered the progenitor of many of the Citrus fruits present in the world. The fruit, a large $20-30 \mathrm{~cm}$, is yellowish, oval, or almost round, sometimes with a slight protuberance at the peduncle and a little pointed at the opposite side. Its peel is very rough and exceptionally thick and represents up to $70 \%$ of the fruit, so, even after removing the seeds and the film between the segments, only $25 \%-30 \%$ of the cedar is edible. In Calabria, cedar is cultivated and worked mainly in the coastal area of the high Tyrrhenian coast of the province of Cosenza, called "Riviera dei Cedri". Cedar is used in the food industry for consumption as a table fruit, and for the preparation of soft drinks and candy fruit, but mostly it is consumed in the pharmaceutical industry for the production of the essential oil. Cedar of Salo (Citrus medica cv. Salò) is used for the production of essence and in the production of commercial juices. It gives, unlike cedar, a completely clear juice, so that many agronomists choose a total abandonment of the cultivation of cedar in favor of those of cedar of Salò. Bergamot (Citrus bergamia Risso) produces a yellow citrus fruit, which-according to some scientists-could be considered as a subspecies of bitter orange or a hybrid derived from bitter orange and lemon. Such products are some of the symbols of excellence of the Calabrian agricultural tradition and represent a great resource for the benefit of the local economy. Bergamot is used almost exclusively for the production of the essential oil, obtained from its peel, and the pulp is considered a merely by-product. On the contrary, the pulp and its juice are a rich source of polyphenols, in particular flavonoids, with attraction for pharmaceutical fields, while searching for new forms of nutraceuticals with beneficial properties for human health [6]. The consumption of polyphenols-rich products, such as Citrus consumption, is associated with a reduced cancer incidence [7]. Flavonoids from Citrus have also antiviral and anti-inflammatory activities [8-10]. They can act beneficially on capillary fragility and inhibit or limit human platelet aggregation [10-13]. The antimicrobial activity originating from components of these species is well founded. The essential oils of different Citrus species act as potent antibacterial agents against several Gram-negative and Gram-positive bacteria $[14,15]$. Flavonoids present in peel of bergamot exhibit antibacterial activity [16]. Further, bergamot juice also exhibited noticeable activity against Helicobacter pylori [17]. However, at least to our knowledge, no papers report the evaluation of the capability of the polyphenolic extracts of these three taxa to inhibit or limit the formation of biofilm by different pathogenic bacteria, nor their effect on bacterial metabolism.

Therefore, the aim of this paper was to study the chemical composition of the extracts obtained from juice and pulp of three Citrus taxa cultivated in the above-mentioned "Riviera dei cedri" and to evaluate their antibacterial activity. In particular, we assessed the inhibitory effect of the bacterial capability to form biofilm and to limit the metabolic activity of biofilm cells, in order to exploit new potential applications of such products, with novel challenges in the field of natural anti-bacterial agents.

\section{Results and Discussion}

\subsection{Chemical Composition of the Extracts}

\subsubsection{Total Polyphenol Content}

Total polyphenol content (TPC) of the ethanolic extracts of peel and pulp of bergamot, cedar, and cedar of Salò ranged between $148.98 \mu \mathrm{g} / \mathrm{g}$ (pulp of cedar) and $1002.3 \mu \mathrm{g} / \mathrm{g}$ of fresh product (peel 
of cedar of Salò). By the whole, the cedar of Salò exhibited—both in peel and in pulp—the highest amount of polyphenols, reaching even $1 \mathrm{mg} / \mathrm{g}$ of fresh product (Table 1).

Table 1. Total polyphenols and antioxidant activity exhibited by the ethanolic extracts obtained from peel and pulp of bergamot, cedar, and cedar of Salò. Total polyphenols are reported as $\mu \mathrm{g}$ gallic acid equivalent (GAE)/gr of fresh product, antioxidant activity was expressed in terms of $\mathrm{EC}_{50}$, representing the effective concentration (mg) capable of inhibiting the 2,2-diphenyl-1-picrylhydrazyl (DPPH) radical activity of $50 \%$ after a 60 -min incubation period.

\begin{tabular}{ccccccc}
\hline & \multicolumn{3}{c}{ Total Polyphenols } & \multicolumn{3}{c}{$\begin{array}{c}\text { Antioxidant Activity } \\
\text { (DPPH Test, EC 50) }\end{array}$} \\
\hline & Bergamot & Cedar & Cedar of Salò & Bergamot & Cedar & Cedar of Salò \\
\hline peel & $748.08 \pm 43.67$ & $291.97 \pm 20.81$ & $1002.3 \pm 54.41$ & $6.47 \pm 0.48$ & $19.40 \pm 1.15$ & $3.96 \pm 0.09$ \\
pulp & $208.02 \pm 14.55$ & $148.98 \pm 14.51$ & $242.73 \pm 15.17$ & $10.99 \pm 0.58$ & $24.22 \pm 1.62$ & $10.46 \pm 1.03$ \\
\hline
\end{tabular}

This indicates the high healthy valence of this product, whose traditional cultivation has been lost over the centuries and is now, at least in Italy, limited to few areas, such as its original location, Calabria, and to the area surrounding the Lake of Garda, and which could represent a product with wide potentialities for the Italian agri-food economy. Similarly, bergamot possesses noticeable nutritional challenge: peel and pulp, in fact, showed 748 and $208 \mu \mathrm{g}$ gallic acid equivalent (GAE)/g of TPC, respectively, indicating that the consumption of just one fruit, which weight ranges generally between 80 and $200 \mathrm{~g}$, can provide the body with a considerable amount of polyphenols. Concurrently, cedar, although containing the lowest amount of total polyphenols both in peel and in pulp, represents proportionally the richest source of total polyphenols among the three taxa analyzed (the cedar fruit can be much heavier than that of bergamot, ranging between 500-600 $\mathrm{g}$ and even to $1.5-2 \mathrm{~kg}$ ).

The amount of polyphenols detected in the peel of the three Citrus could be considered higher than that found in other Citrus species [18]. Polyphenolic content present in cedar was also different compared to that reported by Menichini et al. [19], who detected in the mature fresh fruit of C. medica $123.1 \mathrm{mg}$ of total polyphenols in $100 \mathrm{~g}$ of the mesocarp. However, this discrepancy may be due, more than to the different cultivation area, to the climatic conditions, which are known to influence the metabolism of these molecules within the product.

\subsubsection{Antioxidant Activity}

A strong correlation (Correlation-coefficient $=0.96$ ) between the total polyphenol content and the antioxidant activity exhibited by the peel of all three samples analyzed was observed (Table 1). From this point of view, cedar of Salò was once again extremely interesting: in fact, the value of $\mathrm{EC}_{50}$ exhibited by its peel extract was just $3965 \mathrm{mg}$. Cedar, on the other hand, seemed a much weaker antioxidant agent, so much so that it takes almost $20 \mathrm{mg}$ to inhibit by $50 \%$ the activity of $1 \mathrm{~mL}$ of the 2,2-diphenyl-1-picrylhydrazyl (DPPH) radical. Peel of bergamot showed a good antioxidant activity, although not equal to that exhibited by the peel of cedar of Salò, with an $\mathrm{EC}_{50}$ value of $6.47 \mathrm{mg}$. The values found for bergamot peel, but above all for that of cedar di Salò, can suggest their use as new sources of natural antioxidants, usable as functional ingredients in the food industry. The powder obtained from the entire bergamot fruit has shown, after all, an interesting antioxidant activity in both in vitro and ex vivo studies, which have also shown its ability to limit the endothelial alterations by reducing the resulting stress on the endoplasmic reticulum [20]. Such indications are in line with literature data, which confirm that the essential oil from the bergamot peel has high antioxidant and pro-cholinesterase activities and could be used as a "nutraceutical flavor" for the formulation of food products or nutraceuticals, with particular reference to dietary supplements for elderly populations [21]. While several studies ascertained the biochemical and health characteristics of the bergamot fruit and its different portions, the literature is lacking with regard to cedar of Salò, whose peel has shown remarkable antioxidant activity, as well as the presence of interesting polyphenolic metabolites, with 
known biological and health activities. Our study confirmed not only the nutraceutical potential of the bergamot pulp but once again underlined the nutraceutical potential of cedar of Salò. The scenario resulting from the analysis of the antioxidant activity of the pulp of the three Citrus samples is slightly different. In this case, both the bergamot and the Cedar of Salo pulps exhibited almost the same efficacy in inhibiting 50\% of the activity of the DPPH radical. Once again, cedar, also with regard to the pulp, showed a doubly weaker antioxidant activity (Table 1). However, it should be emphasized that the value found for the pulp of the cedar, although lower also than that resulting from other studies [22], is a respectable value, since it refers to the fresh product, and not to a lyophilized or otherwise heat-treated product.

\subsubsection{UPLC Profile}

Table 2 reported the UPLC polyphenol profile of the extracts.

Table 2. Polyphenol composition of the ethanolic extracts from peel and pulp of bergamot, cedar, and cedar of Salò. The data are reported as average of $\mu \mathrm{g} / \mathrm{g}$ of fresh product \pm standard deviation. Legend = nd: not detected.

\begin{tabular}{|c|c|c|c|c|c|c|}
\hline & \multicolumn{2}{|c|}{ Bergamot } & \multicolumn{2}{|c|}{ Cedar } & \multicolumn{2}{|c|}{ Cedar of Salò } \\
\hline & Peel & Pulp & Peel & Pulp & Peel & Pulp \\
\hline \multicolumn{7}{|l|}{ Acidic phenols } \\
\hline Gallic acid & $24.68 \pm 1.03$ & $54.186 \pm 2.34$ & $39.02 \pm 2.10$ & $22.16 \pm 1.55$ & $33.49 \pm 1.37$ & $16.84 \pm 1.67$ \\
\hline Chlorogenic acid & $71.98 \pm 1.67$ & $28.91 \pm 0.57$ & nd & nd & $116.39 \pm 6.32$ & $45.3 \pm 2.14$ \\
\hline Caffeic acid & nd & nd & nd & nd & $7.11 \pm 0.57$ & $6.97 \pm 0.57$ \\
\hline Coumaric acid & nd & nd & nd & nd & $21.05 \pm 0.57$ & $11.61 \pm 0.57$ \\
\hline Ferulic acid & $181.58 \pm 6.32$ & $48.30 \pm 1.67$ & nd & $113.91 \pm 1.67$ & $295.97 \pm 10.2$ & $106.36 \pm 6.32$ \\
\hline \multicolumn{7}{|l|}{ Flavonoids } \\
\hline Rutin & nd & nd & $115.47 \pm 5.42$ & $19.39 \pm 1.67$ & nd & nd \\
\hline Epicatechin & $73.40 \pm 1.67$ & $26.87 \pm 1.67$ & nd & $9.85 \pm 0.57$ & $105.1 \pm 1.67$ & $44.4 \pm 1.67$ \\
\hline Quercetin & $97.32 \pm 10.2$ & nd & nd & nd & $150.89 \pm 6.32$ & nd \\
\hline Apigenin & nd & nd & nd & nd & $24.26 \pm 1.67$ & nd \\
\hline Catechin & $20.56 \pm 2.14$ & $7.03 \pm 0.57$ & $4.34 \pm 0.57$ & nd & $68.78 \pm 1.37$ & $11.84 \pm 1.37$ \\
\hline Total phenolic acids & 278.24 & 131.40 & 39.02 & 136.07 & 474.01 & 187.08 \\
\hline Total flavonoids & 191.28 & 33.9 & 119.81 & 29.24 & 349.03 & 56.24 \\
\hline Total phenolic compounds & 469.52 & 165.3 & 158.83 & 169.31 & 823.04 & 243.32 \\
\hline
\end{tabular}

The three Citrus always contained more total phenolic acids than flavonoids. In some cases, for example in the pulp of cedar and cedar of Salò, such an amount was almost five times higher with respect to that of flavonoids. The parts of the three Citrus analyzed showed a different amount of phenolic acids. Peel of bergamot exhibited a content of total phenolic acids, which was more than double if compared to what was found in the pulp. Indeed, the peel of Salò cedar contained almost three times more acid phenols than the pulp. Cedar represented an exception, as previously indicated. Its peel had a much lower content of acid phenols $(28.67 \%)$ than those found in the pulp. Cedar showed a lower content of phenolic acids. Indeed, its profile was characterized by the absence of chlorogenic, caffeic, and p-coumaric acids. On the other hand, ferulic acid was detected only in the pulp. Cedar of Salò showed all the phenolic acids identified. In general, we found a greater quantity of individual polyphenols in the peel with respect to the pulp. In some cases, such as that of rutin, the quantity of the same molecule found in the peel was almost 6 times higher than that found in the pulp (115.47 and $19.39 \mu \mathrm{g} / \mathrm{g}$ of fresh product, respectively). The presence of such an important concentration of rutin in the peel of cedar (where this compound represented 39\% of the total polyphenols) is very significant. Rutin ( $3^{\prime}, 4^{\prime}, 5,7$-tetrahydroxy-flavone-3-rutinoside) has been extensively studied due to its anti-inflammatory [23], antibacterial [24], anti-depressant [25], and cancer chemo-preventive [26] activities. Due to its anti-inflammatory properties, rutin has been widely used in the treatment of chronic venous insufficiency; further uses have been suggested for the treatment of glaucoma, hay fever, hemorrhoids, varicose veins, poor circulation, oral herpes, cirrhosis, stress, low serum calcium, 
and cataracts $[27,28]$. Rutin is generally poorly absorbed; however, the use of appropriate natural solvents can improve its absorption and solubilization in the organism. This allows a greater recovery of the molecule, so as to open new frontiers in the field of nutraceuticals [29]. In other cases, some flavonoids were present only in the peel (e.g., quercetin in bergamot; catechin in cedar; quercetin and apigenin in cedar of Salò). Only in one case did we find the presence of a metabolite (epicatechin) in the pulp but not in the peel (of the cedar). Therefore, Karoui and Marzouk reported a higher amount of such a metabolite in juice than in the peel of C. aurantium L. [30]. Among the three Citrus analyzed, cedar of Salò showed the most variegated profile and almost all the known standards available were found both in the pulp and above all in the peel. In cedar of Salò, it is to highlight above all the abundance of the two hydroxycinnamic derivatives, chlorogenic and ferulic acids. The latter was the most abundant metabolite present in the peel $(295 \mu \mathrm{g} / \mathrm{g}$ of fresh product), representing $62 \%$ of the total phenolic acids. The presence of such a high amount of ferulic acid was in agreement with other studies [30,31]. Two flavonoids, epicatechin $(105.1 \mu \mathrm{g} / \mathrm{g}$ of fresh product) and quercetin (which, with $150.89 \mu \mathrm{g} / \mathrm{g}$ of fresh product alone, represented $15 \%$ of the total polyphenols present in that portion of the fruit and more than $50 \%$ of the total flavonoids identified through UPLC) were present mainly in the peel of cedar of Salò. In this fruit, the relative abundance of the two hydroxycinnamic derivatives, chlorogenic and ferulic acids, as well as of the two well-defined flavonoids, can be highlighted with the degree of maturation of the fruit. The presence of apigenin, but not of naringenin (a common secondary metabolite in Citrus fruits), could indicate a high degree of ripeness of the analyzed products. Apigenin, in fact, in the process of biosynthesis of phenylpropanoids, originates from naringenin, which on the one hand leads to the formation of apigenin and on the other gives rise to genistein [32]. Moreover, the high degree of ripeness of the fruits may also explain the significant content of epicatechin, found in the peel and pulp of bergamot and in cedar of Salò. The high ferulic acid content, also found in the other two fruits, and an almost complete absence of caffeic acid (found only in cedar of Salò in very low amounts), confirmed the maturation of the analyzed samples, always keeping in mind the biosynthetic pathway of phenylpronoids and the enzymatic-metabolic steps leading to the synthesis of ferulic acid from caffeic acid [33]. The presence of epicatechin found only in the pulp of the cedar, which is also the only sample presenting rutin, indicated a probable different metabolic pathway in these samples, which led, in the cedar, to the predominance of a flavonoid, rutin, in the peel, and of a hydroxycinnamic acid, ferulic acid, in the pulp.

\subsection{Biological Activity}

\subsubsection{Antibacterial Activity}

In general, all the six extracts exhibited antibacterial activity against the strains tested. Less effective antibacterial activity was exhibited, just against two strains (P. carotovorum and Ps. aeruginosa), by the polyphenolic extract obtained from the bergamot pulp (Table 3).

Table 3. Minimal inhibitory concentration of the polyphenol extracts from the pulp and peel of bergamot, cedar, and cedar of Salo evaluated through the resazurin test, as reported in the Materials and Methods.

\begin{tabular}{lcccccc}
\hline \multicolumn{1}{c}{ MIC $(\mathrm{mg} / \mathrm{mL})$} & \multicolumn{2}{c}{ Bergamot } & \multicolumn{2}{c}{ Cedar } & \multicolumn{2}{c}{ Cedar of Salò } \\
\hline & Peel & Pulp & Peel & Pulp & Peel & Pulp \\
\hline E. coli & 9.00 & 8.00 & 10.00 & 9.00 & 9.00 & 8.00 \\
L. monocytogenes & 8.00 & 7.00 & 7.00 & 8.00 & 8.00 & 7.00 \\
P. carotovorum & 8.00 & $>10.00$ & 9.00 & 9.00 & 9.00 & 10.00 \\
Ps. aeruginosa & 8.00 & $>10.00$ & 7.00 & 10.00 & 8.00 & 9.00 \\
Staph. aureus & 10.00 & 7.00 & 10.00 & 9.00 & 7.00 & 8.00 \\
\hline
\end{tabular}


These results are in agreement with previous studies reporting the effectiveness of action of polyphenols from Citrus versus both Gram-negative and Gram-positive strains [3,12,14]. Concerning cedar of Salò, we usually found a slightly greater efficacy in inhibiting microbial growth exhibited by the extract of the peel compared to that shown by the extract of the pulp. Peel of cedar was slightly more effective than pulp against L. monocytogenes and Ps. aeruginosa. Of particular importance the apparently good antibacterial behavior of the pulp extracts of all three samples versus EHEC E. coli and, that of the pulp of bergamot, against Staph. aureus. The presence of such a variegated pattern of polyphenols within the extracts could be considered important, also due to their influence on colonic microbiota, with positive effects on human health [34-37]. The data obtained could stimulate new studies about the effects of bergamot whole-fruit on selected beneficial or pathogenic gut bacteria that, to the best of our knowledge, appear little studied. This corroborates, once again, with the potentialities of the polyphenols of the pulp of Citrus in restricting the growth of pathogenic bacteria. Moreover, their possible use in food processes, as natural preserving agents, appears of importance. At same time, the effectiveness of some of the extracts to inhibit the growth of the phytopathogenic strain, P. carotovorum, could open new opportunities in the treatment of plants with natural antibiotics.

\subsubsection{Biofilm Formation and Metabolic Activity of Biofilm Cells}

Polyphenols present in the peel of bergamot showed, in general, the ability to inhibit the formation of biofilms by the pathogenic strains used (Figure 1a).

They were active against all pathogens tested, although with different effectiveness. Polyphenols of the pulp of bergamot did not exhibit a wider spectrum of action; they were almost incapable of constraining the biofilm formation by P. carotovorum and Ps. aeruginosa. However, in the other cases, they were much more effective with respect to those of peel, inhibiting the formation of biofilm almost completely (97.61\%). In the case of L. monocytogenes, they inhibited $92.02 \%$ of the biofilm, just with $1.2 \mathrm{mg}$; in addition, $6 \mathrm{mg}$ of such extract inhibited up to $90 \%$ of the biofilm formation by Staph. aureus. Such capability also corroborated with the data concerning the inhibitory action on viability of the cells present inside the biofilm, which was always more effective with respect to that exhibited by polyphenols of peel against E.coli, L. monocytogenes, and Staph. aureus (Figure 1b). At the same time, we noted almost total inactivity of the pulp extract against $P$. carotovorum and Ps. aeruginosa. The polyphenolic extract of bergamot peel, although less effective, proved to be active in inhibiting the formation of biofilm by P. carotovorum (up to $67.72 \%$ inhibition) and Ps. aeruginosa (52.5\% inhibition). The test with MTT showed that the extracts of bergamot peel were not only able to inhibit the formation of biofilm, but also to act on the metabolism of the cells therein, Figure 1b). The behavior exhibited by the polyphenols of cedar was in some cases similar, although with less efficacy (Figure 2a,b).

Only with regard to P. aeruginosa, the inhibitory activity exhibited by cedar peel was much stronger than that exerted by the pulp of cedar at the same quantities of TP used in the experiments $(72.9 \%$ and 3.6\%, respectively, Figure 2a). Pulp of cedar seemed more effective than the peel in inhibiting the formation of biofilm by E. coli and Staph. aureus; this was also reflected in the worse metabolic activity exhibited by the cells of these two strains within the respective biofilms (Figure 2b). Cedar of Salò, in contrast, was overall active and effective in inhibiting biofilm formation (Figure 3).

Also in this case, as already observed for cedar and bergamot, the pulp of cedar of Salò, at the highest of the sub-MIC concentrations used, was more effective than the peel against $L$. monocytogenes and E.coli, and was able to inhibit the metabolic activity of the cells up to 59.7\% (against E. coli, Figure 3a). The action of most of the extracts in blocking both biofilm formation and the metabolic activity of biofilm bacterial cells of the phytopathogen P. carotovorum (Figure $3 \mathrm{~b}$ ) confirmed that such extracts could also find interesting applications in agriculture. 

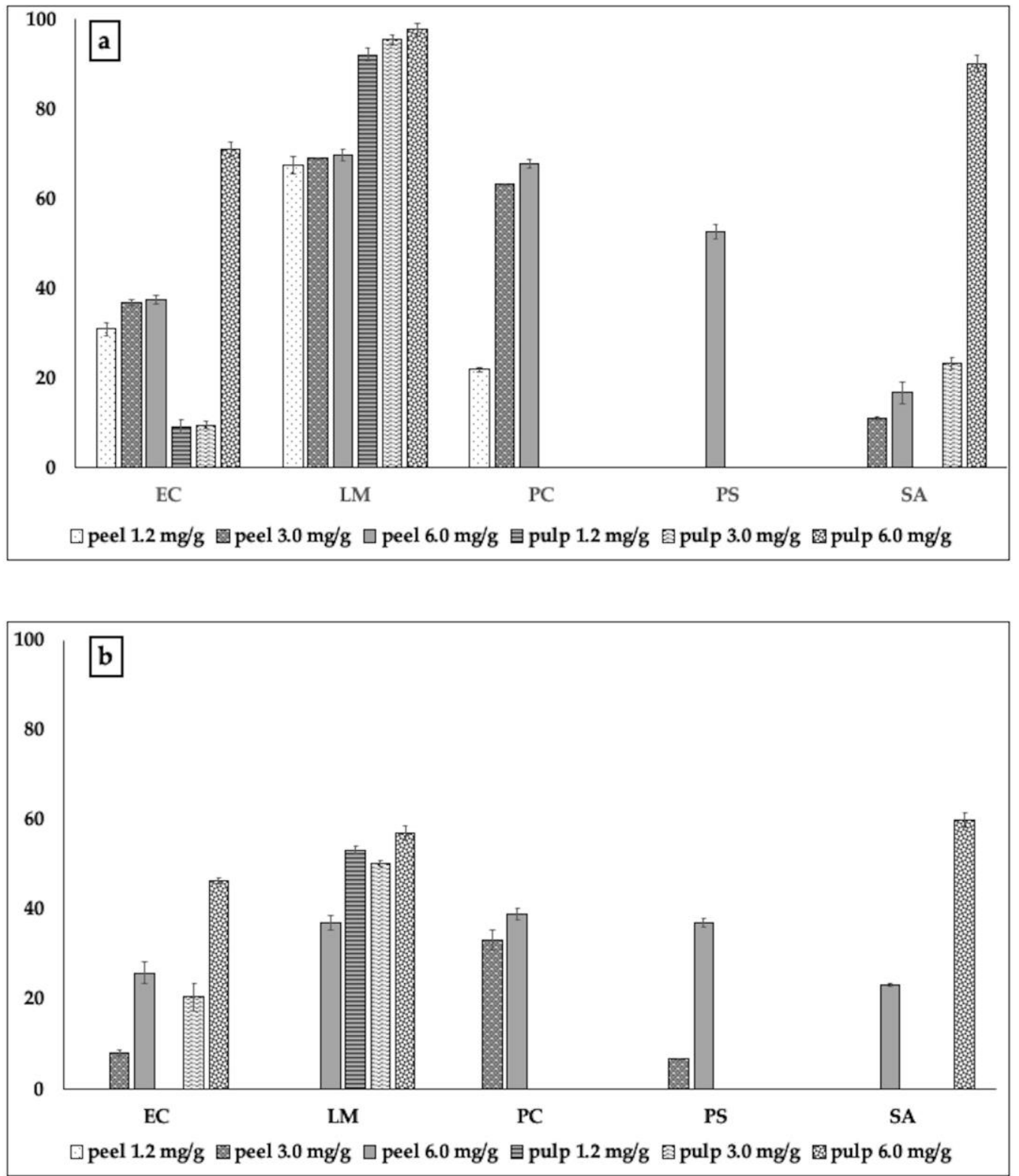

Figure 1. Inhibitory action of the extracts from pulp and peel of bergamot on the bacterial capability to form biofilm (a) and on the metabolic activity of bacterial cells present within the biofilm (b). The test was performed using three sub-minimal inhibitory concentrations of the samples, previously calculated through the resazurin test for each tester pathogenic strain used in the experiments. The data are reported as percentage with respect to the control. Legend: EC: E. coli; LM: L. monocytogenes; PC: P. carotovorum; PS: Ps. aeruginosa; SA: Staph. aureus.

The data acquired showed that the polyphenolic extracts obtained from the two portions (peel and pulp) of the three Citrus taxa were generally able not only to limit the formation of biofilm by pathogenic bacteria, but also to alter the metabolic activity of the cells present within the biofilm, thus counteracting the formation of biofilm on several fronts, including that of acting on the metabolism of biofilm bacterial cells. This confirms the great and interesting applicative versatility of Citrus, whose species can provide extracts or essential oils capable of preventing or at least reducing, the pathogenicity of different bacteria, acting through different mechanisms of action [38]. The presence of flavonoids in the extracts appears to modulate the mechanisms of cellular communication. From the analysis of the polyphenols, however, we could hypothesize that the inhibitory activity against the biofilm and the metabolism of bacterial biofilm cells was due not only to the presence of flavonoids, but 
also to the presence of phenolic acids, in particular chlorogenic and ferulic acids, whose capacity in this sense has been demonstrated by Virkam et al. [39]. Moreover, phenolic acids, such as chlorogenic [40] and ferulic acids [41], are able to prevent and limit the formation of biofilms. In the case of cedar, there is a further consideration linked to the presence of rutin, which was reported for its inhibitory power on the biofilm formation of P. aeruginosa [42]. Here, the presence of rutin meant that especially peel of cedar was able to inhibit the formation of biofilm by Ps. aeruginosa with a percentage equal to $76.3 \%$, and to act on the vitality and metabolism of the cells present in the biofilm, which turned out to be viable and active but much less than half (inhibition $=42.2 \%$ ) compared to untreated bacterial cells.
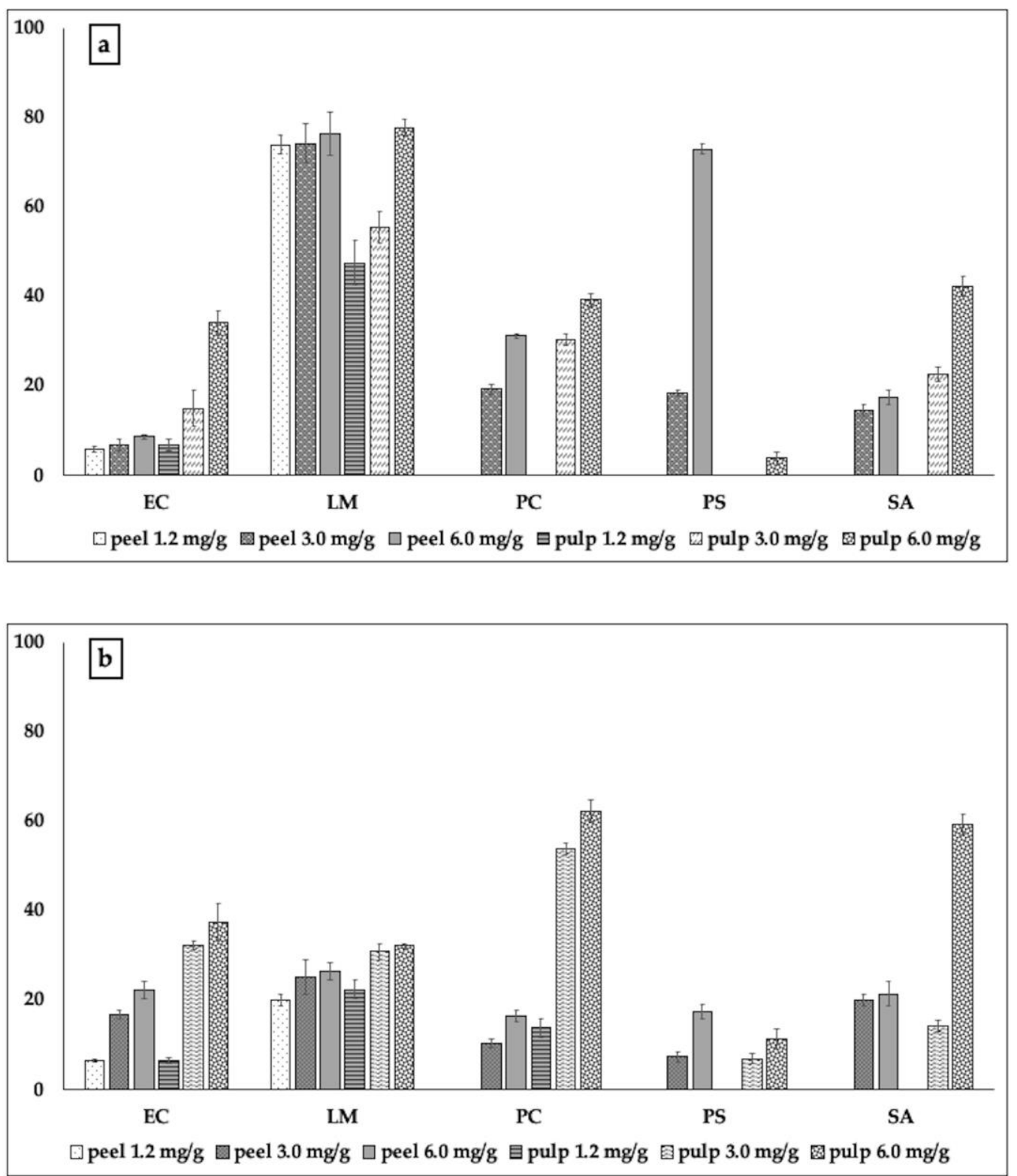

Figure 2. Inhibitory action of the extracts from peel and pulp of cedar, on the bacterial capability to form biofilm (a) and on the metabolic activity of bacterial cells present within the biofilm (b). The test was performed using three sub-minimal inhibitory concentrations of the samples, previously calculated through the resazurin test for each tester pathogenic strain used in the experiments. The data are reported as percentage with respect to the control. Legend: EC: E. coli; LM: L. monocytogenes; PC: P. carotovorum; PS: Ps. aeruginosa; SA: Staph. aureus. 

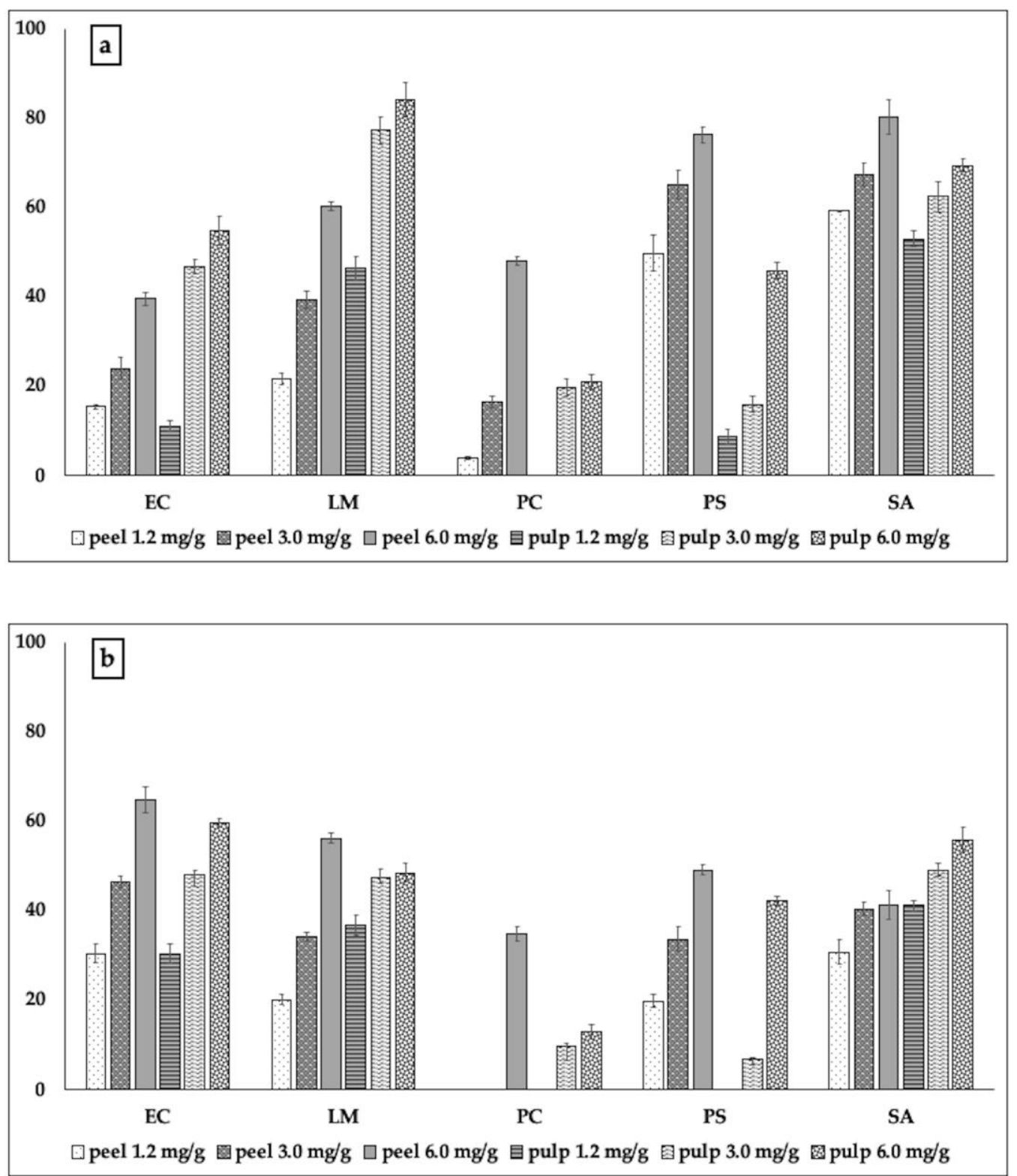

Figure 3. Inhibitory action of the extracts from peel and pulp of cedar of Salò, on the bacterial capability to form biofilm (a) and on the metabolic activity of bacterial cells present within the biofilm (b). The test was performed using three sub-minimal inhibitory concentrations of the samples, previously calculated through the resazurin test for each tester pathogenic strain used in the experiments. The data are reported as percentage with respect to the control. Legend: EC: E. coli; LM: L. monocytogenes; PC: P. carotovorum; PS: Ps. aeruginosa; SA: Staph. aureus.

\section{Materials and Methods}

\subsection{Materials}

Caffeic, ferulic, $p$-coumaric, gallic, and chlorogenic acids, rutin, catechin, quercetin, 2,2-diphenyl1-picrylhydrazyl (DPPH), 3-(4,5-dimethylthiazol-2-yl)-2,5-diphenyl tetrazolium bromide (MTT), dimethylsulphoxide (DMSO), sterile Luria-Bertani broth, tetracycline, ciprofloxacin, HPLC-grade ethanol, 4-methyl-2-pentanol, ethanol, and acetonitrile were purchased from Sigma-Aldrich (Milano, Italy). Apigenin was purchased from Extrasynthese (Genay, France). Ultrapure water was produced by a Milli-Q system (Millipore, Milan, Italy). 


\section{Plant Material}

Fruits of Citrus medica L. (cedar), C. bergamia Risso (bergamot), and Citrus medica cv. Salò (cedar of Salò) were collected in 2015 in S. Maria del Cedro (Cosenza, 39 $45^{\prime} \mathrm{N} 15^{\circ} 50^{\prime} \mathrm{E}$ ), Southern Italy. Professor Vincenzo De Feo identified the plants and provided to store voucher specimens in the Herbarium of the Medical Botany Chair at the University of Salerno.

\subsection{Biochemical Characterization}

Biochemical characterization involved the analysis of the total polyphenol content, the antioxidant activity, and the qualitative-quantitative profile of polyphenols by ultra-pressure liquid chromatography.

\subsubsection{Polyphenol Extraction}

Peel was removed from fruits, carefully avoiding the recovery of the albedo, pounded, and left in contact with ethanol 100\% (1:2 v/v) for $24 \mathrm{~h}$ in the dark at $4{ }^{\circ} \mathrm{C}$. Pulp was homogenized with a domestic homogenizer and, after centrifugation for $5 \mathrm{~min}$ at $3000 \mathrm{rpm}$ (Beckman Italia Cassina de' Pecchi, Milan, Italy), the juice was recovered and centrifuged again for $20 \mathrm{~min}$ at $6000 \mathrm{rpm}$. Then, it was mixed with two volumes of $100 \%$ ethanol, and left at $4{ }^{\circ} \mathrm{C}$ for $24 \mathrm{~h}$.

\subsubsection{Total Polyphenol Content}

The dosage of total polyphenols present in the ethanolic extracts was carried out following the protocol of Singleton and Rossi [43], using the Folin-Ciocalteau reagent. The absorbance was measured at room temperature at $\lambda=760 \mathrm{~nm}$, with a Vary Cary UV/Vis spectrophotometer (Varian Cary Spectrophotometer model 50 MPR, Cernusco sul Naviglio, MI, Italy). The quantification of the total polyphenols was obtained through a calibration curve generated with gallic acid. Results were expressed in terms of concentration $(\mu \mathrm{g})$ of GAE/gr of fresh sample.

\subsubsection{Antioxidant Activity}

The antioxidant activity of the extracts was determined by evaluating their capability to inhibit the activity of the 2,2-diphenyl-1-picrylhydrazyl radical (DPPH test) [44]. The analysis was carried out on microtiter plates, by adding $7.5 \mu \mathrm{L}$ of the samples to $303 \mu \mathrm{L}$ of a solution of DPPH in methanol $(153 \mathrm{mM})$ and measuring the absorbance $\lambda=517 \mathrm{~nm}$ (Varian Cary Spectrophotometer model $50 \mathrm{MPR}$, Cernusco sul Naviglio, MI, Italy). The antioxidant activity was expressed in terms of $\mathrm{EC}_{50}$, representing the effective concentration capable of inhibiting the DPPH radical activity of $50 \%$ after a 60 -min incubation. All experiments were performed in triplicate. The correlation with respect to total polyphenols was calculated through the program Excel (Microsoft, Redmond, WA, USA).

\subsubsection{Polyphenol profile}

The analysis of the polyphenolic profile was carried out following the method of Fratianni et al. [45]. An ultra-pressure liquid chromatograph with diode array detector (UPLC-DAD) (Waters Italia, Sesto San Giovanni (MI), Italy) was used for the analysis; data acquisition was carried out with the Empower Waters software. The analyses were performed at $30^{\circ} \mathrm{C}$ using a BEH $\mathrm{C}_{18}$ column, $1.7 \mu \mathrm{m}$, $2.1 \mathrm{~mm} \times 100 \mathrm{~mm}$. The mobile phase consisted of $7.5 \mathrm{mM}$ acetic acid (eluent A) and acetonitrile (eluent B). The analyses were conducted at a back-pressure value between 6000 and 8000 psi. The DAD detector was programmed to a scanning range between 210 and $400 \mathrm{~nm}$, with a resolution of $1.2 \mathrm{~nm}$. The injection volume was $5 \mu \mathrm{L}$. Quantification of the polyphenols was determined through calibration curves obtained from the polyphenol standards mentioned above. 


\subsection{Antibacterial Activity}

\subsubsection{Microorganisms and Culture Conditions}

Staphylococcus aureus ATCC 25923, Listeria monocytogenes ATCC 7644, EHEC, Escherichia coli DSM 8579, Pseudomonas aeruginosa DSM 50071, and the phytopathogen Pectobacterium carovotorum DSM 102074 were used as test bacterial strains. We previously stored the strains at $-30{ }^{\circ} \mathrm{C}$ in sterile Luria Bertani (LB) broth (Sigma, Milano, Italy) supplemented with 20\% sterile glycerol (Sigma, Milano, Italy). Bacteria were thawed and added (inoculum 2\%) to LB broth. S. aureus, L. monocytogenes, E.coli, and P. aeruginosa were grown for $18 \mathrm{~h}$ at $37^{\circ} \mathrm{C}$ and $80 \mathrm{rpm}$ (Corning LSE, Pisa, Italy). P. carotovorum was grown at $30{ }^{\circ} \mathrm{C}$ and $80 \mathrm{rpm}$. Then, fresh cultures were used as inoculum ( $2 \%$ final concentration) and grown in the conditions above described.

\subsubsection{Minimal Inhibitory Concentration (MIC)}

Values of the Minimal Inhibitory Concentration (MIC) were calculated using the resazurin microtiter-plate assay [46,47]. Two-fold serial dilutions were performed to have $50 \mu \mathrm{L}$ of the test material in serially descending concentrations in each well. A $35 \mu \mathrm{L}$ amount of $3.3 \times$ strength iso-sensitized broth and $5 \mu \mathrm{L}$ of resazurin, used as indicator solution, were added to reach a final volume/well of $240 \mu \mathrm{L}$ with different volumes of sterile Luria-Bertani broth previously set. Lastly, $10 \mu \mathrm{L}$ of bacterial suspension was added to each well to reach a concentration of about $0.5 \mathrm{McF}$ arland $\left(1.5 \times 10^{7}\right.$ cells $\left./ \mathrm{mL}\right)$ (Densitometer cell density turbidity 0.3-15.0 McFarland, CAMLAB, Cambridge, UK). Sterile DMSO and ciprofloxacin (prepared dissolving $1 \mathrm{mg} / \mathrm{mL}$ in DMSO) were used as negative and positive control, respectively. Microtiter-plates were prepared in triplicate and incubated at $37^{\circ} \mathrm{C}$ for $24 \mathrm{~h}$. The lowest concentration at which a color change occurred (from dark purple to colorless) indicated the MIC value.

\subsubsection{Biofilm Inhibitory Activity}

The biofilms of S. aureus, L. monocytogenes E. coli, P. aeruginosa, and P. carovotorum were formed in flat-bottomed 96-well microtiter plates following the method of O'Toole and Kolter [48] using sub-MIC values. In each well, the overnight bacterial cultures were adjusted to $0.5 \mathrm{McFarland}$ $\left(1.5 \times 10^{7}\right.$ cells $\left./ \mathrm{mL}\right)$ (Densitometer cell density turbidity 0.3-15.0 McFarland, CAMLAB, Cambridge, UK) using Luria-Bertani broth. Then, $10 \mu \mathrm{L}$ of the diluted cultures were distributed in each well, and different volumes of the extracts and Luria-Bertani broth were added, to reach a final volume of $200 \mu \mathrm{L} /$ well. Microplates were completely covered with parafilm, to avoid the evaporation of samples with relative loss of volume and incubated for $48 \mathrm{~h}$. Planktonic cells were removed and the attached cells were gently washed twice with sterile physiological saline solution. Then, $200 \mu \mathrm{L}$ of methanol/well, which was left for $20 \mathrm{~min}$ to fix the sessile cells, was added. The methanol was discarded, and the plates were left under laminar flow cap until complete dryness of samples (at least $30 \mathrm{~min}$ ). The staining of the adhered cells was obtained by adding $200 \mu \mathrm{L}$ of $2 \% w / v$ crystal violet solution to each well that was left for $20 \mathrm{~min}$. Wells were gently washed and left to dry. A volume of $200 \mu \mathrm{L}$ of glacial acetic acid $20 \% w / v$ was added to allow the release of the bound dye. The absorbance was measured at $\mathrm{OD}=540 \mathrm{~nm}$ (Varian Cary). Evaluation of the biofilm inhibition was calculated (percentage) with respect to that of control (cells grown without the presence of the extracts). Triplicate tests were done, and the average results were taken for reproducibility.

\subsubsection{Metabolic Activity of Biofilm Cells}

The effect of the extracts from bergamot, cedar, and cedar of Salò on the metabolic activity of cells present in the biofilm was evaluated through the MTT colorimetric test, modifying the method of Kairo et al. [49] as follows. After $48 \mathrm{~h}$ of bacterial growth in the 96-well microtiter plates, planktonic cells were removed and $150 \mu \mathrm{L}$ of PBS and $30 \mu \mathrm{L}$ of $0.3 \%$ MTT were added. Then, microtiter plates were kept at $37^{\circ} \mathrm{C}$. After $3 \mathrm{~h}$, the MTT solution was removed and $200 \mu \mathrm{L}$ of DMSO/well were added, 
to allow the dissolution of the formazan crystals formed in the wells. After $3 \mathrm{~h}$ incubation at $37^{\circ} \mathrm{C}$, resulting purple formazan derivatives were dissolved in DMSO and measured at $\mathrm{OD}=570 \mathrm{~nm}$ (Varian Cary). Triplicate tests were done, and the average results were taken for reproducibility.

Author Contributions: Conceptualization, F.F. and F.N.; Methodology, F.F. and F.N.; Investigation, F.F., F.N., A.C., V.D.F., M.N.O.; Writing-Original Draft Preparation, F.N.; Writing-Review \& Editing, F.N. and V.D.F.; Visualization, R.C.; Funding Acquisition, F.N. and R.C.

Funding: This research was supported by the Calabria Region PSR 2007-2013 “Calabria Salus" and by the by the Italian MIUR project "PON4a2_Be \& Save Project 2007-2013".

Acknowledgments: The authors are grateful to Eng. Antonio d'Acierno for the graphical support.

Conflicts of Interest: The authors declare no conflict of interest.

\section{References}

1. Nazzaro, F.; Fratianni, F.; Coppola, R. Quorum sensing and phytochemicals. Int. J. Mol. Sci. 2013, 14, 12607-12619. [CrossRef] [PubMed]

2. Noumi, E.; Snoussi, M.; Merghni, A.; Nazzaro, F.; Quindós, G.; Akdamar, G.; Mastouri, M.; Al-Sieni, A.; Ceylan, O. Phytochemical composition, anti-biofilm and anti-quorum sensing potential of fruit, stem and leaves of Salvadora persica L. methanolic extracts. Microb. Pathog. 2017, 109, 169-176. [CrossRef] [PubMed]

3. Uzun, A.; Yesiloglu, T. Genetic diversity in Citrus. In Genetic Diversity in Plants; Caliskan, M., Ed.; InTech: Rijeka, Croatia, 2012; pp. 213-230.

4. Gabriele, B.; Fazio, A.; Dugo, P.; Costa, R.; Mondello, L. Essential oil composition of Citrus medica var. liscia L. cv. Diamante (Diamante citron) determined after using different extraction methods. J. Sep. Sci. 2009, 32, 99-108.

5. Savo, V.; Caneva, G.; Guarrera, P.M.; Reedy, D. Folk phytotherapy of the Amalfi Coast (Campania, Southern Italy). J. Ethnopharmacol. 2011, 135, 376-392. [CrossRef] [PubMed]

6. Pernice, R.; Borriello, G.; Ferranca, R.; Borrelli, R.C.; Cennamo, F.; Ritieni, A. Bergamot: A source of natural antioxidants for functionalized fruit juices. Food Chem. 2009, 112, 545-550. [CrossRef]

7. Li, W.Q.; Kuriyama, S.; Li, Q.; Nagai, M.; Hozawa, A.; Nishino, Y.; Tsuji, I. Citrus consumption and cancer incidence: The Ohsaki cohort study. Int. J. Cancer. 2010, 127, 1913-1922. [CrossRef]

8. Xu, J.J.; Wu, X.; Li, M.M.; Li, G.Q.; Yang, Y.T.; Luo, H.J.; Huang, W.H.; Chung, H.Y.; Ye, W.C.; Wang, G.C.; et al. Antiviral Activity of Polymethoxylated Flavones from "Guangchenpi", the Edible and Medicinal Pericarps of Citrus reticulata 'Chachi'. J. Agric. Food Chem. 2014, 62, 2182-2189. [CrossRef]

9. Kim, H.K.; Jeon, W.K.; Ko, B.S. Flavanone Glycosides from Citrus junos and their Anti-Influenza Virus Activity. Planta Med. 2001, 67, 548-549. [CrossRef]

10. Tripoli, E.; La Guardia, M.; Giammanco, S.; Di Majo, D.; Giammanco, M. Citrus flavonoids: Molecular structure, biological activity and nutritional properties: A review. Food Chem. 2007, 104, 466-479.

11. Ting, S.V.; Roussef, R.L. Citrus Fruits and Their Products: Analysis and Technology; Marcel Dekker: New York, NY, USA, 1986.

12. Mandalari, G.; Bennett, R.N.; Bisignano, G.; Saija, A.; Dugo, G.; Lo Curto, R.B.; Faulds, C.B.; Waldron, K.W. Characterization of flavonoids and pectins from bergamot (Citrus bergamia Risso) peel, a major by-product of essential oil extraction. J. Agric. Food Chem. 2006, 54, 197-203. [CrossRef]

13. Benavente-García, O.; Castillo, J. Update on uses and properties of Citrus flavonoids: New findings in anticancer, cardiovascular, and anti-inflammatory activity. J. Agric. Food Chem. 2008, 56, 6185-6205. [CrossRef] [PubMed]

14. Fisher, K.; Phillips, C.A. The effect of lemon, orange and bergamot essential oils and their components on the survival of Campylobacter jejuni, Escherichia coli O157, Listeria monocytogenes, Bacillus cereus and Staphylococcus aureus in vitro and in food systems. J. Appl. Microbiol. 2006, 101, 1232-1240. [CrossRef] [PubMed]

15. Aliberti, L.; Caputo, L.; De Feo, V.; De Martino, L.; Nazzaro, F.; Souza, L. Chemical Composition and in Vitro Antimicrobial, Cytotoxic, and Central Nervous System Activities of the Essential Oils of Citrus medica L. cv. 'Liscia' and C. medica cv. 'Rugosa' Cultivated in Southern Italy. Molecules 2016, 21, 1244. [CrossRef] [PubMed] 
16. Mandalari, G.; Bennett, R.N.; Bisignano, G.; Trombetta, D.; Saija, A.; Faulds, C.B.; Gasson, M.J.; Narbad, A. Antimicrobial activity of flavonoids extracted from bergamot (Citrus bergamia Risso) peel, a byproduct of the essential oil industry. J. Appl. Microbiol. 2007, 103, 2056-2064. [CrossRef]

17. Filocamo, A.; Bisignano, C.; Ferlazzo, N.; Cirmi, S.; Mandalari, G.; Navarra, M. In vitro effect of bergamot (Citrus bergamia) juice against cagA-positive and-negative clinical isolates of Helicobacter pylori. BMC Complement. Altern. Med. 2015, 15, 256. [CrossRef]

18. Ghasemi, K.; Ghasemi, Y.; Ebrahimzadeh, M.A. Antioxidant activity, phenol and flavonoid contents of 13 Citrus species peels and tissues. Pak. J. Pharmacol. Sci. 2009, 22, 277-281.

19. Menichini, F.; Loizzo, M.R.; Bonesi, M.; Conforti, F.; De Luca, D.; Statti, G.A.; de Cindio, B.; Menichini, F.; Tundis, R. Phytochemical profile, antioxidant, anti-inflammatory and hypoglycemicpotential of hydroalcoholic extracts from Citrus medica L. cv. Diamante flowers, leaves and fruits at two maturity stages. Food Chem. Toxicol. 2011, 49, 1549-1555. [CrossRef]

20. Gabriele, M.; Frassinetti, S.; Caltavuturo, L.; Montero, L.; Dinelli, G.; Longo, V.; Di Gioia, D.; Pucci, L. Citrus bergamia powder: Antioxidant, antimicrobial and anti-inflammatory properties. J. Funct. Foods 2017, 31, 255-265. [CrossRef]

21. Tundis, R.; Loizzo, M.R.; Bonesi, M.; Menichini, F.; Mastellone, V.; Colica, C.; Menichini, F. Comparative study on the antioxidant capacity and cholinesterase inhibitory activity of Citrus aurantifolia Swingle, $C$. aurantium L., and C. bergamia Risso and Poit. Peel Essential Oils. J. Food Sci. 2012, 77, H40-H46. [CrossRef]

22. Munwar, S.; Roy, H.; Rahaman, S.A. Antioxidant and free radical scavenging activity of Citrus medica. Int. J. Pharma Res. Health Sci. 2015, 3, 810-816.

23. Umar, S.; Mishra, N.K.; Pal, K.; Sajad, M.; Neha; Ansari, M.M.; Ahmad, S.; Katiyar, C.K.; Khan, H.A. Protective effect of rutin in attenuation of collagen-induced arthritis in Wistar rat by inhibiting inflammation and oxidative stress. Indian J. Rheumatol. 2012, 7, 191-198. [CrossRef]

24. Cushnie, T.P.T.; Lamb, A.J. Antimicrobial activity of flavonoids. Int. J. Antimicrob. Agents 2005, 26, 343-356. [CrossRef] [PubMed]

25. Machado, D.G.; Bettio, L.E.B.; Cunha, M.P.; Santos, A.R.S.; Pizzolatti, M.G.; Brighente, I.M.C.; Rodrigues, A.L.S. Antidepressant-like effect of rutin isolated from the ethanolic extract from Schinus molle L. in mice: Evidence for the involvement of the serotonergic and noradrenergic systems. Eur. J. Pharmacol. 2008, 587, 163-168. [CrossRef] [PubMed]

26. Araújo, J.R.; Gonçalves, P.; Martel, F. Chemopreventive effect of dietary polyphenols in colorectal cancer cell lines. Nutr. Res. 2011, 31, 77-87. [CrossRef] [PubMed]

27. Chen, M.; Zhang, X.; Wang, H.; Lin, B.; Wang, S.; Hu, G. Determination of rutin in rat plasma by ultra performance liquid chromatography tandem mass spectrometry and application to pharmacokinetic study. J. Chromatogr. Sci. 2015, 53, 519-525. [CrossRef]

28. Morling, J.R.; Yeoh, S.E.; Kolbach, D.N. Rutosides for treatment of post-thrombotic syndrome. Cochrane Database Syst. Rev. 2015, 9, CD005625. [CrossRef]

29. Faggian, M.; Sut, S.; Perissutti, B.; Baldan, V.; Grabnar, I.; Dall'Acqua, S. Natural deep eutectic solvents (NADES) as a tool for bioavailability improvement: Pharmacokinetics of rutin dissolved in proline/glycine after oral administration in rats: Possible application in nutraceuticals. Molecules 2016, 21, 1531. [CrossRef]

30. Karoui, I.J.; Marzouk, B. Characterization of bioactive compounds in tunisian bitter orange (Citrus aurantium L.) peel and juice and determination of their antioxidant activities. BioMed Res. Int. 2013, 2013, 1-12. [CrossRef]

31. Robbins, R.J. Phenolic acids in foods: An overview of analytical methodology. J Agric Food Chem. 2003, 51, 2866-2887. [CrossRef]

32. Available online: https://www.kegg.jp/kegg-bin/search_pathway_text?map=map\&keyword=epicatechin\& mode $=1 \&$ viewImage $=$ true (accessed on 9 December 2019).

33. Available online: https://www.kegg.jp/kegg-bin/search_pathway_text?map=map\&keyword=ferulic\&mode= $1 \&$ viewImage $=$ true (accessed on 9 December 2019).

34. Hervert-Hernández, D.; Pintado, C.; Rotger, R.; Goñi, I. Stimulatory role of grape pomace polyphenols on Lactobacillus acidophilus growth. Int. J. Food Microbiol. 2009, 136, 119-122. [CrossRef]

35. Dueñas, M.; Cueva, C.; Muñoz-González, I.; Jiménez-Girón, A.; Sánchez-Patán, F.; Santos-Buelga, C.; Moreno-Arribas, M.V.; Bartolomé, B. Studies on modulation of gut microbiota by wine polyphenols: From isolated cultures to omic approaches. Antioxidants 2015, 4, 1-21. [CrossRef] [PubMed] 
36. Cardona, F.; Andrés-Lacueva, C.; Tulipani, S.; Tinahones, F.J.; Queipo-Ortuño, M.I. Benefits of polyphenols on gut microbiota and implications in human health. J. Nutr. Biochem. 2013, 24, 1415-1422. [CrossRef] [PubMed]

37. Nazzaro, F.; Fratianni, F.; d'Acierno, A.; Coppola, R. Gut microbiota and polyphenols: A strict connection enhancing human health. In Advances in Food Biotechnology; Ravishankar Rai, V., Ed.; Wiley-Blackwell: Chichester, UK, 2015; pp. 335-350.

38. Castillo, S.; Heredia, N.; Arechiga-Carvajal, E.; García, S. Citrus Extracts as Inhibitors of Quorum Sensing, Biofilm Formation and Motility of Campylobacter jejuni. Food Biotechnol. 2014, 28, 106-122. [CrossRef]

39. Vikram, A.; Jayaprakasha, G.K.; Jesudhasan, P.T.; Pillai, S.D.; Patil, B.S. Suppression of bacterial cell-cell signalling, biofilm formation and type III secretion system by citrus flavonoids. J. Appl. Microbiol. 2010, 109, 515-527. [CrossRef] [PubMed]

40. Naveed, M.; Hejazi, V.; Abbas, M.; Kamboh, A.A.; Khan, G.J.; Shumzaid, M.; Ahmad, F.; Babazadehh, D.; Fang Fang, X.; Modarresi-Ghazanij, F.; et al. Chlorogenic acid (CGA): A pharmacological review and call for further research. Biofilm prevention and control by dietary phytochemicals. Biomed. Pharmacother. 2018, 97, 67-74. [CrossRef] [PubMed]

41. Borges, A.; Abreu, A.C.; Malheiro, J.; Saavedra, M.J.; Simões, M. Biofilm prevention and control by dietary phytochemical. In Microbial Pathogens and Strategies for Combating Them: Science, Technology and Education; Méndez-Vilas, A., Ed.; Formatex Research Center: Badajoz, Spain, 2013; pp. 33-42.

42. Deepika, M.S.; Thangam, R.; Sakthidhasan, P.; Arun, S.; Sivasubramanian, S.; Thirumurugan, S. Combined effect of a natural flavonoid rutin from Citrus sinensis and conventional antibiotic gentamicin on Pseudomonas aeruginosa biofilm formation. Food Control 2018, 90, 282-294. [CrossRef]

43. Singleton, V.L.; Rossi, J.A. Colorimetry of total phenolics with phosphomolybdic-phosphotungstic acid reagents. Am. J. Enol. Viticult. 1965, 16, 144-158.

44. Brand-Williams, W.; Cuvelier, M.E.; Berset, C. Use of a free radical method to evaluate antioxidant activity. LWT Food Sci. Technol. 1995, 28, 25-30. [CrossRef]

45. Fratianni, F.; Nazzaro, F.; Marandino, A.; Fusco, M.R.; Coppola, R.; De Feo, V.; De Martino, L. Biochemical composition, antimicrobial activities, and anti-quorum-sensing activities of ethanol and ethyl acetate extracts from Hypericum connatum Lam. (Guttiferae). J. Med. Food 2013, 16, 454-459. [CrossRef]

46. Sarker, S.D.; Nahar, L.; Kumarasamy, Y. Microtitre plate-based antibacterial assay incorporating resazurin as an indicator of cell growth, and its application in the in vitro antibacterial screening of phytochemicals. Methods 2007, 42, 321-324. [CrossRef]

47. Nazzaro, F.; Fratianni, F.; Cozzolino, R.; Martignetti, A.; Malorni, L.; De Feo, V.; Cruz, A.G.; d'Acierno, A. Antibacterial Activity of Three Extra Virgin Olive Oils of the Campania Region, Southern Italy, Related to Their Polyphenol Content and Composition. Microorganisms 2019, 7, 321. [CrossRef] [PubMed]

48. O'Toole, G.A.; Kolter, R. Flagellar and twitching motility are necessary for Pseudomonas aeruginosa biofilm development. Mol. Microbiol. 1998, 30, 295-304. [CrossRef] [PubMed]

49. Kairo, S.K.; Bedwell, J.; Tyler, P.C.; Carter, A.; Corbel, M.J. Development of a tetrazolium salt assay for rapid determination of viability of BCG vaccines. Vaccine 1999, 17, 2423-2438. [CrossRef]

Sample Availability: Samples of the compounds are not available from the authors.

(C) 2019 by the authors. Licensee MDPI, Basel, Switzerland. This article is an open access article distributed under the terms and conditions of the Creative Commons Attribution (CC BY) license (http://creativecommons.org/licenses/by/4.0/). 